\title{
THE ACUTE EFFECT OF TRANSCRANIAL DIRECT CONTINUOUS STIMULATION IN SJOGREN'S SYNDROME IN THE QUALITY OF SLEEP AND FATIGUE
}

Virginia Fernandes Moça Trevisani1,*, Aléxia Gabriela da Silva Vieira1, Ana Carolina Pereira Nunes Pinto ${ }^{1}$, Sara Regina Piva², Samantha Guerra Cabó Nunes Gomes ${ }^{1}$, Aline Pereira da Rocha ${ }^{1}$, Daniela Regina Brandão Tavares ${ }^{1}$, Márcia Valéria de Andrade Santana ${ }^{1}$, Fania Cristina Santos ${ }^{1}$, Felipe Fregni ${ }^{3}$

1.Universidade Federal de São Paulo, São Paulo (SP), Brazil. 2.University of Pittsburgh, Pittsburgh (PA), USA. 3.Harvard Medical School, Boston (MA), USA.

*Corresponding author:vmoca@uol.com.br

\section{BACKGROUND}

The primary Sjögren's syndrome (pSS) is the third more frequent rheumatic syndrome, affecting about 0.04 a $0.08 \%$ of the world population. In addition to the extraglandular symptoms completely changing the lives of most people affected by this disease, fatigue and quality of sleep are variables that health professionals should be concerned about and investigate alternative treatments. The transcranial direct current stimulation (tDCS) is a low-cost, innovative intervention that has shown promise to decrease fatigue. However, it has never been examined in pSS.

\section{MATERIALS AND METHODS}

The objective of this study was to assess the effect of one session of tDCS on fatigue and sleep quality in patients with pSS. We performed a double-blind randomized sham-controlled clinical trial. The session lasted 20 min, with an intensity of 2 mA. The anode was placed over the right dorsolateral prefrontal cortex and the cathode over the left dorsolateral prefrontal cortex. The sites receiving stimulation corresponded to F4 and F3, respectively. We used the Visual Analogue Scale (VAS) for assessing the quality of sleep and fatigue, before and after the session.

\section{RESULTS}

Thirty-six patients were eligible to participate in this study. No difference between groups were found for any of the outcomes. However, a large effect size was found regarding the effect of tDCS on sleepiness. The results are summarized in Table 1.

Table 1. Effect of tDCS on sleepiness.

\begin{tabular}{|c|c|c|c|c|c|c|c|}
\hline & & $\begin{array}{l}\text { Before the session } 1 \\
\quad \text { Mean (SD) }\end{array}$ & $\begin{array}{l}\text { After the session } 1 \\
\text { Mean (SD) }\end{array}$ & $\begin{array}{l}\text { Mean } \\
\text { change }\end{array}$ & $\begin{array}{l}\text { Mean difference } \\
\text { change }(95 \% \mathrm{Cl})\end{array}$ & $\begin{array}{l}\text { Effect } \\
\text { size }\end{array}$ & $\begin{array}{l}\text { P-value } \\
\text { (2-tailed) }\end{array}$ \\
\hline VAS fatigue & $\begin{array}{l}\text { Active } \\
\text { Sham }\end{array}$ & $\begin{array}{l}4.46(3.62) \\
4.29(2.56)\end{array}$ & $\begin{array}{l}3.56(2.64) \\
3.91(2.74)\end{array}$ & $\begin{array}{l}-1.12(3.14) \\
-0.37(2.53)\end{array}$ & $\begin{array}{c}-0.74 \\
(-2.68 \text { to } 1.19)\end{array}$ & 0.26 & 0.44 \\
\hline $\begin{array}{c}\text { VAS } \\
\text { quality of sleep }\end{array}$ & $\begin{array}{l}\text { Active } \\
\text { Sham }\end{array}$ & $\begin{array}{l}6.78(3.35) \\
4.90(2.94)\end{array}$ & $\begin{array}{l}4.69(2.90) \\
3.63(2.71)\end{array}$ & $\begin{array}{l}-2.09(3.36) \\
-1.26(3.05)\end{array}$ & $\begin{array}{c}-0.83 \\
(-3.01 \text { to } 1.34)\end{array}$ & 0.25 & 0.44 \\
\hline VAS sleepiness & $\begin{array}{l}\text { Active } \\
\text { Sham }\end{array}$ & $\begin{array}{l}4.47(3.77) \\
1.77(2.36)\end{array}$ & $\begin{array}{l}3.43(3.68) \\
3.06(2.46)\end{array}$ & $\begin{array}{l}-1.03(4.17) \\
1.28(2.84)\end{array}$ & $\begin{array}{c}-2.32 \\
(-4.74 \text { to } 0.09)\end{array}$ & 0.65 & 0.06 \\
\hline
\end{tabular}

The first line of every variable shows the results for the active group; the second line shows the results for the placebo group.

\section{CONCLUSION}

The tDCS seems to acutely improve sleepiness in patients with pSS. Further larger randomized controlled trials with more tDCS sessions are needed to determine the mechanisms by which tDCS works and to provide dose refinement for possible implementation of tDCS treatments in pSS patients. 